\title{
Sztuka modlitwy w doświadczeniu filokalistycznym Emiliana (Vafeidisa) Simonopetrity
}

\author{
bp Andrzej Borkowski \\ Katedra Teologii Prawosławnej, Uniwersytet w Białymstoku \\ borkowskiunath@yahoo.gr
}

\begin{abstract}
bp Andrzej Borkowski, The art of prayer in the Philokalia experience of the elder Aimilianos (Vafeidis) of Simonopetra, Elpis, 19 2017: 191-200.

Abstract: The Elder Aimilianos defines prayer as charisma, heavenly joyful meeting and communion of God with a man. The art of prayer in the Philokalia experience of the elder is dependent of the state of our mind. It should be clean, deprived of any extraneous content in waiting for the coming of God. Real prayer rejects all sadness and pusillanimity. There are following frames, in which prayer can come into being: peace, silence, peace of mind, absolute calmness and being silent. In fact, prayer is not done by a man itself. It is only begun by a man, only wanted by a man. That is Holy Spirit, who fills it. Prayer is our everyday life obligation. One may say about a success during prayer, only when it becomes our place of refuge. In his teaching, the Elder distinguishes between internal and external factors, which have influence on prayer. First of them are: condition of our spirit and its relationship with God. In that case, prayer is a homily of the mind, breath of the spirit, bowing to God. The second factors are: knowledge about various ways of prayer, necessary to the mystical inspiration of the Holy Spirit. We are talking here about participation in Divine Liturgy, constant prayer, Jesus prayer, praying rule, consideration in concentration and silence. Prayer is not isolated itself, but is closely related to participation in services, thanksgiving, vigil, in order to overcome the bodily passions. At the same time, the elder warns, that prayer does not become a reason for isolation, because in that case, it will be lying and insincere. Prayer is not mental work, which is tiresome, but it is full of dynamism directed to God.
\end{abstract}

\begin{abstract}
Streszczenie: Starzec Emilian określa modlitwę charyzmą, niebiańskim radosnym spotkaniem i komunią Boga z człowiekiem. Sztuka modlitwy w doświadczeniu filokalistycznym starca jest uzależniona od stanu naszego umysłu, który powinien być czysty, pozbawiony wszelkiej obcej treści w oczekiwaniu przyjścia Boga. Prawdziwa modlitwa odrzuca wszelki smutek i małoduszność, zaś ramki prawa w których może zaistnieć są określane przez pokój, ciszę, spokój ducha, absolutne wyciszenie i milczenie. W rzeczywistości modlitwa nie jest czymś, co czyni sam człowiek, jedynie to rozpoczyna, tego pragnie, ale wypełnia ją Duch Święty. Modlitwa jest naszą powszednią powinnością życiową. O sukcesie podczas modlitwy możemy mówić wówczas, gdy stanie się naszym miejscem schronienia. W swym nauczaniu starzec rozróżnia czynniki wewnętrzne i zewnętrzne, które mają wpływ na modlitwę. Do pierwszych zalicza stan naszego ducha i jego związek z Bogiem, zaś modlitwę określa mianem homilii umysłu, oddechem ducha, pokłonem oddawanym Bogu. Do drugich zalicza wiedzę o różnych sposobach modlitwy, niezbędną do mistycznego natchnienia przez Ducha Świętego. Takimi są uczestnictwo w liturgii Bożej, modlitwa nieustanna, jezusowa i własna, reguła modlitewna, rozważania w skupieniu i wyciszeniu. Modlitwa nie izoluje się sama w sobie, ale pozostaje w ścisłym związku z uczestnictwem w nabożeństwach, dziękczynieniem, czuwaniem, w celu pokonania cielesnych namiętności. Starzec przestrzega przy tym, aby modlitwa nie stała się powodem odizolowania, ponieważ wówczas stanie się kłamliwą i nieszczerą. Modlitwa nie jest pracą umysłową która męczy, ale jest pełnią dynamizmu nakierowanego na Boga.
\end{abstract}

Keywords: Elder Aimilianos of Simonopetra, prayer, Philokalia, monasticism, Mont Athos

Słowa kluczowe: starzec Emilian Simonopetrita, modlitwa, Filokalia, monastycyzm, Góra Athos

Współczesne doświadczenie teologiczne na ścieżkach diakonii duszpasterskiej i poświęcenia ludowi Bożemu, zawdzięczamy poszukiwaniom duszpasterskich wzorców pośród historycznej „obecności” Cerkwi, która została ugruntowana w jej przeszłości i rozciąga się na jej eschatologiczną przyszłość. Badacz drogi duchowej współczesnego Prawosławia staje z szacunkiem i pobożnością wobec poszczególnych ascetycznych paradygmatów Ojców i nosicieli ducha ( $\pi v \varepsilon v \mu \alpha \tau o \varphi o ́ \rho \omega v)$, przedstawicieli każdej epoki. Z pełną szczerością można ich scharakteryzować jako współczesnych hezychastów lub współczesnych epigonów odrodzenia filokalicznego. Owi Ojcowie obdarzeni charyzmatem płodności duchowej oraz odrodzania i kierownictwa dusz, zaadoptowali ascetyczną cechę i takt oraz hezychastyczny duch, od swych starszych poprzedników, ojców filokalistów. Stali się współczesnymi ojcami duchowymi młodzieży, przekształcającymi i ożywiającymi współczesny ruch monastyczny. Jednym słowem stali się kontynuatorami wielowiekowej tradycji prawosławnej ojcostwa duchowego. Osobowość szacownego starca Emiliana (Vafeidisa), ihumena monasteru Simonopetra w Autonomicznej Republice Góry Athos, należy dokładnie do tej kategorii współczesnych gigantów ducha ${ }^{1}$.

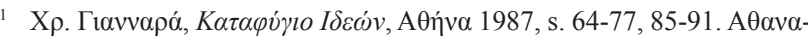

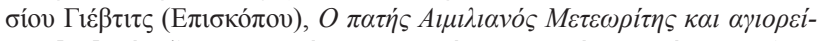

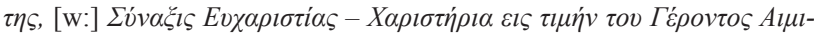

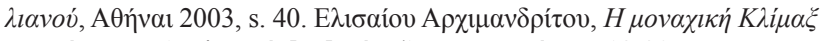

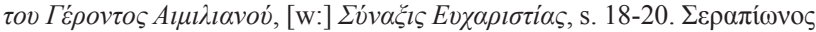

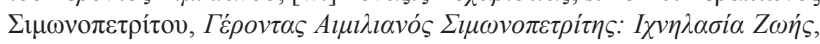

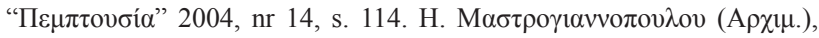


Starzec znając wewnętrzną głębię modlitwy, określa ją mianem „oddechu ducha, podążaniem ku Bogu”2. Modlitwa, w jego nauczaniu, łączy się z pozostałymi czynnościami przykazania miłości do Boga. Nie izoluje się sama w sobie, ale pozostaje w ścisłym związku z uczestnictwem w nabożeństwach, dziękczynieniem, czuwaniem ${ }^{3}$, w celu pokonania cielesnych namiętności i pozyskania siły duchowej. Jedynie pod takim warunkiem może stać się dialogiem z Bogiem oraz spotkaniem i obcowaniem z Duchem Świętym ${ }^{4}$. Jest doświadczeniem zmagań, nawoływań, cichego skupienia i objawienia ${ }^{5}$, umartwianiem ,starego człowieka", czerpaniem z dóbr niebiańskich, zanurzeniem w życiodajnej boskości, pochwyceniem umysłu, przybliżeniem Triadycznego misterium.

Centrum modlitwy jest serce, a jej przeszkodą niewiedza, własna wola i zapomnienie. Gdy człowiek doświadcza Bożej światłości, wówczas dościga celu modlitwy. Zostaje ,pochwycony” przez Boga w Duchu Świętym wewnątrz ludzkiego serca, komunii i identyfikacji Boga $\mathrm{z}$ modlącą się ludzka naturą w jednej osobie i hipostazie tak, aby pokonał podziały natury w jedności hipostazy i stał się bogopodobnym. Modlitwa jest charyzmą, niebiańskim radosnym spotkaniem i komunią Boga z człowiekiem, z prostotą i w duchowych objęciach, bez zmartwień i rozpaczy 6 .

Do pozyskiwania łaski Bożej i prawdziwego uczestnictwa w życiu Boga niezbędne jest uczestnictwo w liturgii Bożej ${ }^{7}$ Bez liturgii nie można zrozumieć lub prowadzić modlitwy i życia duchowego. Modlitwa jest homilią umysłu do Boga. Modlitwa w samym swym początku jest zjednoczeniowym zwrotem i ukłonem umysłu ku Bogu. Jakim zatem jest stan w którym powinien znajdować się umysł, aby mógł zwrócić się do swego Władcy? Aby mógł prowadzić rozmowę z Nim bez uczestnictwa w niej pośredników? Aby mógł łączyć się bezpośrednio i bez przeszkód z Bogiem? Starzec Emilian korzysta z terminu św. Nila, „homilia”. Homilia lub po prostu dialog jest wyjściem nas samych ku innym, oczywiście w przypadku dialogu szczerego i prawdziwego. Gdy mówimy, że nasz umysł rozma-

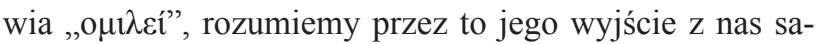
mych. Należy przy tym być ostrożnym. Modlitwa nie jest zwykłą pogadanką, ani zbiorem myśli ${ }^{8}$.

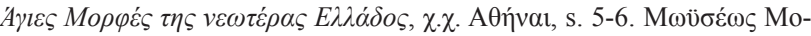

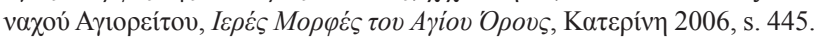

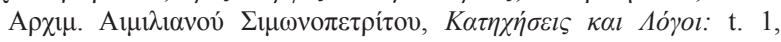

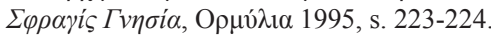

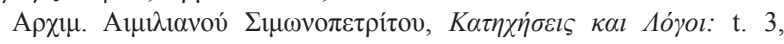

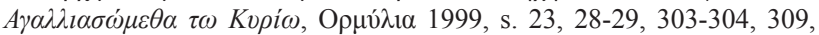
358.

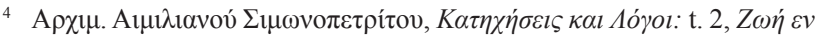

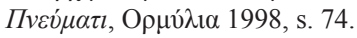

5 Por. Rz. 8,19; Flp. 1,20.

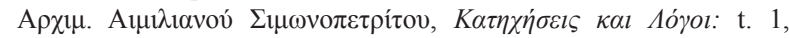

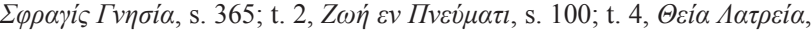

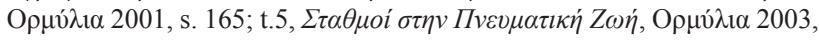
s. $215-217,231$.

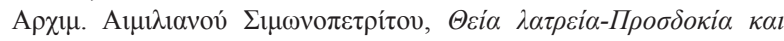

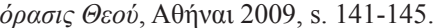

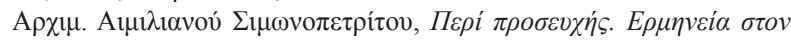

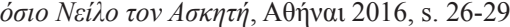

Modlitwa nie zawiera się w słowach podziękowania: „że nie stało mi się nic złego; że mam zdrowie”. To nie jest modlitwa, nawet jeśli posiada pewien zewnętrzny model modlitwy. Nie można oczywiście zabronić takiego modelu, nie jest niczym złym, ale jest raczej zatroskaniem umysłu, a nie jego ukierunkowaniem ku Bogu. Homilia umysłu oznacza, pozostawanie umysłu skupionym, którego nie zaprzątają myśli, aby cały umysł mógł być pochwycony, aby przylgnął do Boga.

Homilia jest pojęciem wspólnoty z Bogiem, jednak na tym etapie nie można powiedzieć, że posiadam łączność z Tym, który jest jeszcze dla mnie niedosięgalny. Wspólnota jest uwarunkowana odwiedzinami Boga, jest zatem późniejszym stadium. Uwarunkowanie jest czysto ludzkie i polega na tym aby umysł nie spekulował, aby nie był zajęty myślami, ale pozostał sam. Homilia jest czymś bardzo głębokim i wewnętrznym. Jednak pozostajemy jeszcze przy człowieku w początkującej fazie, który udaje się na poszukiwanie Boga. Modlitwa duchowa posiada doświadczenie empiryczne oraz możliwość rozwoju. Skądś się zaczyna, rozwija się i dokądś zmierza. W trakcie tej drogi wstępowania ku Bogu znajduje się etap wspólnoty. Jednak, aby dojść do tego etapu należy się potrudzić, nieraz latami ${ }^{9}$.

Mojżesz ujrzał gorejący krzew, który nie spalał się. Poszedł więc aby zbliżyć do niego. Działanie to jest modelem rozmowy, zasięgu umysłu przy modlitwie i wyraża jak jest postrzegana obrazowo modlitwa. $Z$ tego miejsca rozpoczyna się doświadczenie duchowe. Pomimo, że krzew był materialny, był modelem obecności Boga, ukrywał się w nim w sposób mistyczny sam Bóg, dlatego Mojżesz został powstrzymany przed zbliżeniem się do niego. Bóg rzekł do niego aby uprzednio zdjął sandały ze stóp. Jeśli zatem Mojżesz został powstrzymany, jak my możemy zbliżyć się do Niego? Krzew jesteśmy w stanie pojąć, posiadamy wyobrażenie, ale jak możemy stać się współrozmówcami z Bogiem? Jak osiągnę z Nim łączność, jak będę obcował z Nim? Jak zbliżę się do Tego, którego nie mogę ujrzeć ani zrozumieć?

Umysł, aby skierował się ku Bogu, aby kontemplował jedynie Boga musi pozbyć się myśli. Powinien porzucić

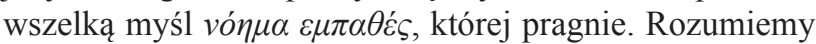
przez to oczywiście wszelką grzeszną myśl. W rzeczywistości oznacza to każdą myśl, do której czuje pociąganie nasz umysł. Zetem, umysł powinien być zwrócony do siebie, aby mógł z kolei skierować się ku Bogu. Umysł powinien być czysty, bez treści, bez wyobrażania sobie czegoś ${ }^{10}$. Kiedy umysł jest czysty? Gdy jest gotowy, uprzątnięty, pozbawiony wszelkiej obcej treści i oczekuje Boga. Pan Bóg przychodzi jedynie do przygotowanych serc, uprzątniętych, aby je wypełnić. Ponieważ Bóg jest Bogiem zazdrosnym $^{11} \mathrm{i}$ nie toleruje innej obecności.

Rezultatem czystości jest beznamiętność. Modlić się beznamiętnie znaczy, bez napięcia. Umysł znajduje się w bezruchu, bez działania, wyciszony, aby Bóg przyszedł

\footnotetext{
Tamże, s. 29-31.

10 Tamże, s. 33-34.

11 Zob. E $\xi .20,5$.
} 
i połączył się z nim. Umysł powinien być pusty i przede wszystkim niezakłócony przez funkcję gniewliwą $(\theta v \mu 1-$

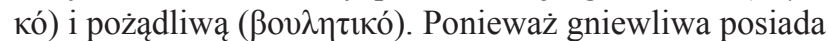
określoną treść, odczucie i wiedzę, pojmowanie i określone zdanie, natomiast pożądliwa część dostarcza energii. Zatem należy ograniczyć i zamknąć część gniewliwą i pożądliwą w umyśle lub wykluczyć poza swój umysł, co zabezpiecza w pewien sposób dziewiczy umysł, aby mógł wejść w kontakt $\mathrm{z}$ Bogiem i modlić się ${ }^{12}$.

Gdy człowiekowi jest darowany od Boga płacz, posiada dwa uczucia: bezgranicznej radości i dziękczynienia Bogu. Ludzie, którzy zwykle modlą się ze łzami są osobami z przykrymi doświadczeniami, którzy nie mają umysłu skierowanego ku Bogu, ale ku bolesnym doświadczeniom i troskom. To osoby, które nie wiedzą jak się modlić, a modląc się nie używają wolnego umysłu, natomiast używają w swej kontemplacji serca, mianowicie swe pożądliwości. Dlatego jeśli dokładnie zastanowimy się to zauważymy że wiele razy podczas modlitwy odczuwamy ciężar, zmartwienie, niepokój. Taka modlitwa może jednak stać się przyczyną ${ }^{13} \mathrm{i}$ środkiem z pomocą którego zostaniemy poprowadzeni ku prawdziwej modlitwie, ale sama w sobie jeszcze nie jest modlitwą.

Prawdziwa modlitwa odrzuca wszelki smutek i małoduszność. Dlatego, gdy prorok Dawid pragnął poruszyć swoją duszę ku modlitwie, pamiętał co uczynił Bóg jemu i ludowi izraelskiemu, aby czerpać słowa wdzięczności, radości, upojenia serca, i aby w ten sposób mógł rozmawiać z Bogiem. Należy zatem rozróżnić co oznacza płacz. Istnieje wówczas gdy towarzyszą mu radość i dziękczynienie, mianowicie uczucie wdzięczności i spełnienia się. Dusza wyciszona i spokojna, gdy ma w sobie wdzięczność i radość, wówczas może modlić się zaczynając od łez. Wszelka inna modlitwa jest tylko pewną umową w relacjach z Bogiem. Nie odrzucamy i takiego stanu, gdyż może stać się kiedyś zaczynem, dzięki któremu zostaniemy poprowadzeni ku modlitwie prawdziwej. Modlitwa istnieje tam, gdzie następuje upojenie duszy z Bogiem oraz radość w sercu. Jeśli nie jesteśmy wdzięczni, nie możemy czynić modlitwy. Jeśli jest $\mathrm{w}$ nas sprzeciw i ciężar, zmartwienie, ból i pożądliwość wówczas nie ma mowy o modlitwie. Wówczas każda próba modlitwy napotka przed sobą barierę ${ }^{14}$.

Dar łez na modlitwie otrzymujemy, po pierwsze, ku pomnożeniu odwagi i ku wytchnieniu w zmaganiach duchowych; po drugie, ku lepszemu zrozumieniu, że jesteś grzesznikiem i powinieneś wyznać swe grzechy przed Bogiem; po trzecie, ku przebłaganiu Pana naszego Jezusa Chrystusa. O łzy prosimy Boga, aby zmiękczył naszą duszę, abyśmy okazali skruchę oraz zostały nam przebaczone nasze grzechy ${ }^{15}$.

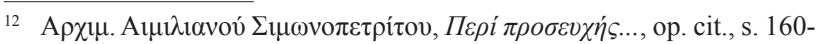

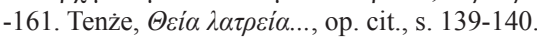

13 Zob. Rz. 8,28.

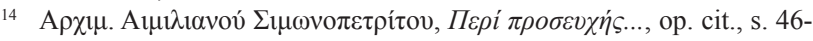

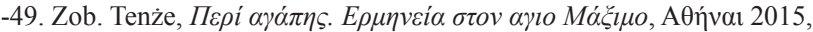
s. $63-67$

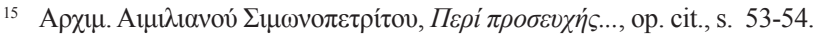

Stając na modlitwę, należy w pewien sposób zamknąć się, po pierwsze, od samego siebie, po drugie, od innych, mianowicie zamknąc się w swym skarbcu ${ }^{16}$ i uzyskać uspokojenie myśli i powrót umysłu do siebie samego. Należy zatem osiągnąć stan równowagi somatycznej, duchowej i psychicznej, który pomoże w modlitwie. Wszelki zgiełk, myśli, namiętności i pragnienia, należy oddalić od siebie. Podczas modlitwy mogą wystąpić określone problemy, które ujawnią się za przyczyną naszego stanu psychicznego, a nie wskutek samej modlitwy. Możemy odczuwać pewne utrudnienia ze strony pracy żołądka, serca, głowy. Mogą również pojawić się różnego rodzaju stany zmartwienia, zawroty głowy, niepokoje, rozdarcia. Nie są jednak rezultatem modlitwy, ale pochodzą z nas samych. Modlić się należy z siłą, z natężeniem, mężnie i w atmosferze pragnienia kontynuacji, gdyż w modlitwie wstępujemy w niewidoczna walkę z demonem i samym sobą. Dwie rzeczy stoją na przeszkodzie w modlitwie, troski i myśli.

Przyjrzeliśmy się wewnętrznym czynnikom, które wpływają na modlitwę. Do takich zaliczyliśmy stan naszego ducha i jego związek z Bogiem. Samą zaś modlitwę określiliśmy homilią, pokłonem oddawanym Bogu, próbą dotknięcia krzewu gorejącego.

Skoro zapoznaliśmy się i przezwyciężyliśmy trudności psychiczne, przejdźmy do pewnych trudności zewnętrznych. Zewnętrzna pokusa aby nam zaszkodzić musi znaleźć odpowiedni grunt. Musi odnaleźć we mnie część pobudliwą, która podda się pokusie. Po czym pragnienie wewnętrzne szuka ujścia na skutek kuszenia ${ }^{17}$.

Jeśli widzę $\mathrm{w}$ innym człowieku rywala lub wroga, czuję wewnętrzne odpychanie, wówczas ten stan burzy beznamiętność. W stanie beznamiętności, mogę łatwo rozmawiać $\mathrm{z}$ drugim człowiekiem o Bogu. Jednak gdy łatwo doznajemy przykrości, wówczas nasza dusza w swej impulsywnej pobudliwości nie jest w stanie uchwycić łagodnego powiewu Ducha, który nas obmywa ze wszystkich stron. Zatem ramki prawa w których może poruszać się, funkcjonować, czy zaistnieć modlitwa są określane przez pokój, ciszę, spokój ducha, absolutne wewnętrzne wyciszenie i milczenie. Jedynie w ten sposób możemy praktykować modlitwę.

W celu prowadzenia modlitwy, należy odrzucić strach przed wszelkimi pokusami, przezwyciężając powody na skutek których nam dokuczają. Nie należy traktować ich jak przeszkodę w kontynuowaniu modlitwy. Nawet największa spośród pokus jest kolejną lekcją, jak obracać się w życiu duchowym, jak podążać w nim przy pomocy rozróżnienia i rozsądku ${ }^{18}$.

Człowiek melancholijny, bolejący, smutny i pełen żalu, który cały czas coś przeżywa nie może prowadzić prawidłowej modlitwy, która połączy go z Bogiem. Najpierw powinien pokonać swoje psychiczne i duchowe problemy, mianowicie powinien uregulować swe relacje z Bogiem i z samym sobą i dopiero wówczas będzie w stanie modlić

\footnotetext{
16 Mt. 6,6.

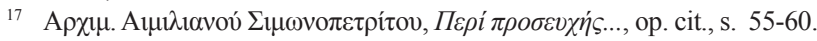

18 Tamże, s. 63-64.
} 
się prawdziwie. Starzec Emilian odwołuje się do św. Nila, który nie mówi o modlitwie jako słowu ku Bogu, ale o tej, która rozumiana jest jako słowo z Bogiem, lub jako łączność, komunia, zwrócenie się i zjednoczenie z Bogiem ${ }^{19}$.

W rzeczywistości modlitwa nie jest czymś co czyni sam człowiek, jedynie to rozpoczyna tego pragnie, ale ostatecznie jego pragnienie wypełnia i wykonuje Duch Święty. Modlimy się, jednak w istocie to Duch Święty modli się, to On jest tym który daje nam natchnienie, jest wykonawcą. Ja decyduje się na modlitwę, zaś Duch Święty modli się za mnie, ma się rozumieć w mym umyśle. Dlatego nie ma łatwiejszej rzeczy od tego, aby ktoś czynił taką silną modlitwę. Wyobraźmy sobie proroka Daniela myślącego jak ma pokonać otaczające go lwy. Na pewno inny na jego miejscu od razu pogubiłby się, zaś prorok wpadając do jamy bez postronnych myśli oddaje się czystej modlitwie. W rezultacie przychodzi Duch Święty i zamyka paszcze lwom, oczyszcza serce, odrzuca wszelką trudność ${ }^{20}$.

Jedynym bogiem, zdolnym do przeciwstawienia się samemu Bogu lub człowiekowi jest nasze ego, nasz król. Jeśli zatem pragniemy modlić się chwalebnie, w każdej godzinie powinniśmy wyprzeć się samego siebie, opustoszyć

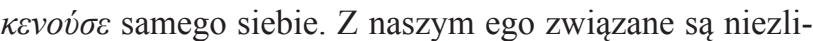
czone cierpienia, z którymi zmagamy się w naszym życiu. W celu wyzbycia się jego, po pierwsze w naszym życiu należy zastąpić nasze ego naszym bliźnim. Należy usunąć nasze ego, nie w sposób psychologiczny, ale w pojęciu duchowym. Po drugie, to na co nie mamy wpływu, to niezbadane wyroki i perypetie życiowe. Jeśli nie nauczymy się nie zadręczać się perypetiami życiowymi, ciągle będziemy siebie rozdrażniać i w konsekwencji będziemy zawsze negatywnie ustosunkowani do tego co nam przyniesie życie. Należy nauczyć się spokoju i obojętności wobec wszystkiego. Kto nie potrafi żyć i poruszać się swobodnie pośród trudności nie stanie się nigdy człowiekiem modlitwy. To znaczy, że nie będę modlić się o zażegnanie trudności życiowych, jak zwykle mają w zwyczaju ludzie, ale będę się modlił o pogodzenie wewnętrznego stanu ducha w sytuacji gdy jestem doświadczany troskami i trudnościami, abym pozostał z Bogiem. Nic absolutnie nie przeszkadza nam w naszej modlitwie z Bogiem. Jedyną przeszkodę stanowi postawa naszego ego. Dlatego potrzebujemy opustoszenia $(\kappa \varepsilon ́ v \omega \sigma \eta)$ siebie od wszystkiego, z czego składa się nasze ego, głównie nasze pragnienia i nasza wola ${ }^{21}$.

Zatem nie ma niczego co by mogło powstrzymać modlitwę. Powstrzymującym modlitwę może być jedynie nasza własna wola oraz wrażenie, że modlitwa jest czymś niezmiernie trudnym. Nikt kto doświadczył modlitwy nie powie, że jest trudna. Jedyną ogromną trudnością, którą spotykamy na modlitwie, jest niedowiarstwo $\mathrm{w}$ modlitwę, brak „filozofii”, wiedzy i zrozumienia. Ewidentnym oddziaływaniem świata jest thumaczenie, że modlitwa to jeden wielki problem lub że jest skomplikowanym systemem oraz potrzebuje określonej techniki. Natomiast, tak

\footnotetext{
Tamże, s. 66

20 Tamże, s. 68

21 Tamże, s. 71-73.
}

naprawdę jest stanem który musi być zainicjowany przez nas, naszą wolę, który tworzy w nas sam Bóg. Dlatego z taką łatwością Bóg osiąga przemianę w ludziach.

Każde ludzkie wstępowanie przynosi sobą zejście ku nam Boga. Odczuwajmy zatem, ze nasza troska, staranie oraz nasze zajęcie, czyli modlitwa jest tak prosta ${ }^{22}$, jest źródłem radości a nie problemem. Ćwiczmy się w niej z lekkością, radością, usilną chęcią, jak coś co jest osiągane przez nas, nie zaś jak coś co czynie w godzinę nabożeństwa. Wówczas dusza, jeśli tego pragnę, może się sama modlić, cokolwiek innego będę czynił. Powinniśmy poczuć jak łatwą jest modlitwa, ponieważ nie dzieje się za sprawą naszej siły, ale za sprawą otrzymania, przyjęcia Boga, zawsze przychodzącego ku nam. Zatem należy czynić naszą powinność z pełną świadomością, że jest ona każdemu z nas dana. Tak jak przeciągam dłoń, aby pochwycić pewien przedmiot, czymś takim jest właśnie modlitwa, mogę ja uchwycić, gdyż daruje mi ja sam Bóg, wystarczy aby mój umysł pragnął wejść do swojej izdebki. ${ }^{23}$

Modlitwa jest naszą powszednią życiową czynnością. Można oczywiście mówić o określonej technice, systemie modlitwy lub właściwościach i skutkach modlitwy, o przygotowaniu się do modlitwy, jakie warunki powinniśmy spełnić, aby Bóg usłyszał naszą modlitwę. Jeśli to wszystko wypełnimy znajdziemy się na terenie nie prawosławnym, nauka o niej stanie się scholastyczną i bardziej upodobni się na protestancką. Może się wydawać, ze nie wyrażamy się tak jasno, jak to uczyniłaby systematyczna analiza modlitwy. Jak jednak jest możliwym, aby w momencie gdy chcemy się pomodlić, zaglądać co piszą o niej w książkach, ten system nie jest ostatecznie praktyczny, nie dotyka naszej duszy. Cerkiew na swój sposób kładzie podwaliny w naszym umyśle i sercu naszej wiary. Kieruje nasz wzrok ku filozoficznemu $\varphi \imath \lambda o ́ \sigma o \varphi \alpha$ ujrzeniu czym jest modlitwa ${ }^{24}$, ku zrozumieniu jej ważności, objawiania przez modlitwę samego Boga oraz poznania jej siły i zawierzenia jej. Słowa kierowane do nas przez Cerkiew są bardzo latwe, jeśli nie w pojmowaniu rozumem, to przynajmniej w naszych sercach, kiedy wkładamy działanie w modlitwę, kiedy staje się czynem.

Jeśli ktoś się modli, gdy na wieczornej modlitwie zmaga się z obezwładniającym go snem, wygodą, egoizmem, gdy dokłada starań, aby jego życie stało się spalająca się wonnością za swych bliźnich, aby nie czynił nikomu krzywdy, zmartwienia, nie przyczyniał bólu nie obrażał i nie lekceważył nikogo nawet w umyśle, wówczas wszystko co tyczy się modlitwy pojmuje swym umysłem, a przede wszystkim sercem ${ }^{25}$.

Wiedza o Bogu i uczestnictwo w Jego radości jest analogiczna $\mathrm{z}$ tym jakimi są nasze zmagania duchowe, po

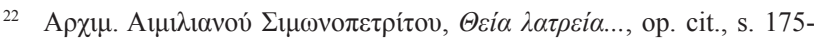
-178 .

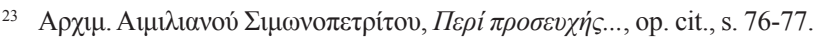

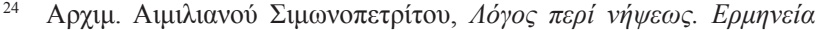

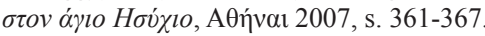

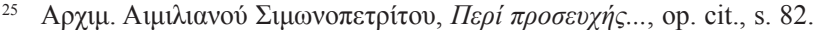

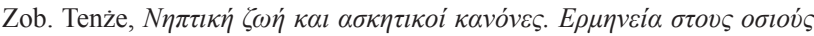

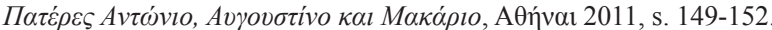


to by stać się modlitewnym bytem. Człowiek, który decyduje się na modlitwę posiada w sobie miłość i nigdy nie otwiera ust aby obmawiać innych. Ten kto decyduje się na modlitwę potrafi oprzeć się wszelkim trudnościom i doświadczeniom życiowym. Potrafi odnaleźć się w każdej sytuacji: biedzie, bogactwie, pośród dobrych i złych, ludzi kochających, nienawidzących oraz oczerniających. Zawsze pozostaje obojętny, potrafi wspaniale przystosować się do każdej sytuacji i być radosnym. Czym bardziej się modli, tym bardziej opiera się nie odczuwa otaczających go trudności. Człowiek modlitwy to ten który nie tylko potrafi znosić wszelkie pomówienia i oszczerstwa, które ranią ludzi kierujacych się wartościami przyziemnymi, ale potrafi pomimo to radować się. Weseli się gdy jest oskarżany, pomawiany i deptany. To charakterystyczna cecha człowieka pragnącego się modlić26.

Wielokrotnie będzie nam modliło się wspaniale, odczujemy słodycz, pocieszenie Boże i Jego obecność w nas. Innym razem, pomimo że się namęczymy nie osiągniemy pokładanego w modlitwie celu. Przyczyna nie leży w tym jak powinienem się skupić oby osiągnąć stan modlitewny. Sukcesem modlitwy jest to, jeśli stanie się moim miejscem schronienia, mianowicie abym nauczył się zawsze modlić. Co czyni w tym celu Bóg? Często, nawet jeśli bardzo zmęczę się, nie otrzymuję upragnionych rezultatów modlitwy. On pragnie abym upraszał o nią jeszcze silniej. Należy dążyć, aby nasza modlitwa stawała się doskonałą, silną, aby przyciągała i darowała nam całego Boga. Czy zatem pośpiech jest wskazany? Pragnienie otrzymania od razu rezultatów, słodyczy i łaski modlitwy nie jest działaniem według Boga, ale według człowieka. Jest egoistycznym żądaniem zapłaty w zamian za trud modlitwy. Takie relacje nie są szczere, gdyż są skierowane na egoistyczne dążenie do osiągnięcia korzyści. Podczas modlitwy prawidłowej, należy przygotować się na odwiedziny szatana, pragnącego nas od niej odciągnąć, jednak z chwilą pojawienia się aniołów, demony pierzchają. Podczas braku modlitwy szatan nam nie szkodzi, zaledwie rozpoczniemy dobra modlitwę, nadchodzi szatan ${ }^{27}$.

Modlitwa odmawiana jest na wiele sposobów. Każdy człowiek, analogicznie do swego charakteru znajduje swój sposób, który pomału się zmienia. Przykładowo, dziś stwierdzam, że bliską memu sercu jest modlitwa wymawiana na głos. Innym razem odkrywam, że jeszcze bliższą jest ta gdy poruszam jedynie ustami ze słowami „Panie Jezu Chryste, zmiłuj się na de mną grzesznym”. Jeszcze innym zauważam, że lepiej poruszać przy wymawianiu modlitwy jedynie językiem lub skoordynować ją z wydechem i wdechem przez gardło. Jeszcze innym, gdy łączymy ją $\mathrm{z}$ uderzeniami serca. Istota modlitwy zawiera się w odnalezieniu sposobu, który w danej chwili przynosi nam kożyść, jutro odkryjemy inny sposób. ,Jutro” może być po miesiącu, po pięciu lub dwudziestu latach ${ }^{28}$.

Odwołując się do św. Nila starzec Emilian nie chce

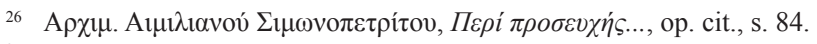

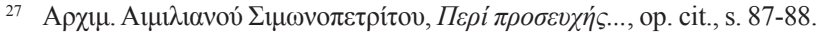

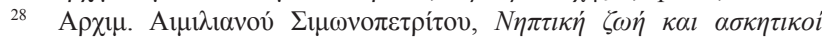

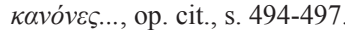

aby każdy modlił się w różnorodny sposób. Wszystkich nas chce natchnąć abyśmy modlili się podobnie, ale analogicznie do usposobienia, wytrzymałości i poziomu naszych zmagań. Modlitwy świętych posiadają wspólne cechy charakterystyczne, sposób jednak zmienia się tak na zewnątrz jak wewnątrz. Przykładowo, jedni wznoszą ręce ku górze inni klęczą, jedni modlą się na stojąco inni siedząc. Jedni powtarzają w sobie „Panie Jezu”, inni „Panie” lub „Jezu”, inni modlą się w czytając teksty modlitw. Jednak wszystkie sposoby są tym samym, są środkami dzięki którym każdy z nas może pomieścić i wyrazić samego siebie. Czy zatem potrzebujemy posiadać wiedzę o różnych sposobach modlitwy? Oczywiście, potrzebujemy posiąść znajomość różnych sposobów modlitwy, aby nasza modlitwa została natchniona mistycznie przez Ducha Świętego. Jeśli nie posiadamy tej znajomości nie możemy modlić się. Pomimo to, jeśli posiadamy taką wiedzę, nie znaczy jeszcze że modlimy się, niezbędne jest pragnienie. Początkiem wszelkiego zła jest niewiedza a wszelkiego dobra znajomość i pragnienie. Nasza modlitwa jest mistycznym zwróceniem się ku nam Ducha Świętego, jest uderzeniem strun naszej duszy przez Niego. Dzieje się tak, gdyż tego pragniemy, przygotowujemy się aby stać się godnymi umieszczenia w sobie Ducha Świętego. Powinniśmy wiedzieć w jaki sposób prosić, albowiem „nie otrzymujemy ponieważ źle prosimy"29. Może nie byłyby potrzebne różne sposoby modlitwy, może mogłaby wystarczyć jedynie modlitwa „Ojcze nasz” lub przypowieść o synu marnotrawnym lub kazanie na Górze. Jednak jesteśmy tak zatwardziali i skrzywieni oraz łatwo zapominamy o miłości Boga, że sam Bóg nam o tym przypomina na wszelkie sposoby ${ }^{30}$.

W komentarzach na kanony monastyczne św. Antoniego Wielkiego ihumen Emilian podkreśla, że modlitwa nieustanna jest nierozłączna z potrzebą dziękczynieniem Boga za wszystko co spotykamy w życiu. Modlimy się i wydaje się nam, że nas nie słyszy Bóg, prosimy o zdrowie a ono stale się pogarsza, wszystkie sprawy przychodzą wbrew naszej woli. Kto się nie nauczy dziękować za wszystko Panu Bogu nie ma szans na progres duchowy. Człowiek musi nauczyć się dziękczynienia Bogu za wszelkie doświadczenia pochodzące od bliźniego lub od demonów ${ }^{31}$. W innym miejscu zaznacza, że nieustanna modlitwa wyzwala człowieka z niewoli. Człowiek pod wpływem obcych sił może zrozumieć jaka namiętność go zniewoliła. Gdy jednak modli się, z jej pomocą, gdyż modlitwa jest Bożą synergią, pozbywa się wszelkiej niewoli umysłu, serca i woli. Modlitwy nie ocenia się jedynie ze względu na jakość ale przez łzy, czy wzruszamy się, czy męczymy się czy nie, ale także ze względu na ilość i nieustanność. Nie raz mówimy, że lepiej pomodlić się jedną godzinę i osiągnąć poczucie modlitwy, niż dwadzieścia godzin bez żadnego uczucia. W tej sytuacji jedynie usiłujemy ukryć nasze przestępstwo. Prawidłowym jest modlenie się jak mogę więcej, kładąc przy tym zasadę aby modlić się jak najlepiej

\footnotetext{
29 Jak. 4,3.

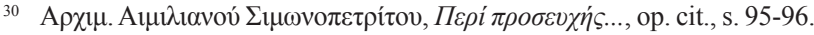

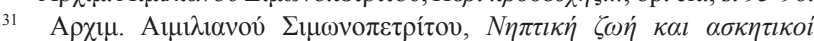

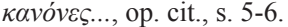


i twórczo. Gdy modlimy się nieustannie, nawet w obliczu trudności, przykrości, wewnętrznego rozdarcia czy klęsk, osiągamy wolność $\mathrm{c}^{32}$.

Modlitwa Jezusowa jest największym osiągnięciem człowieka tu na ziemi. Jest nieustanną wspólnotą z Bogiem. Nie ma żywszego działania, wydajniejszego ziarna, lepszego środka przekazu ku niebu, od modlitwy jezusowej, tym bardziej kiedy stanie się ustawiczną oraz naszą nieodzowną naturalną funkcją życiową. Oczywiście, to nie ja nauczę siebie ciągłego odmawiania modlitwy jezusowej. Co zatem czynię? Staram się jak mogę pamiętania o nieustannym powtarzaniu modlitwy, aby mój umysł nie rozpraszał się, ale aby przyzwyczaił się śledzić za rozumem. Jeśli tak uczynię, już nie ja czynię modlitwę ale sama działa we mnie, jako rezultat początkowego trudu. Wówczas nawet jeśli śpię, budzę się z modlitwą w sercu i umyśle ${ }^{33}$. Podczas modlitwy jezusowej odrzucamy wszelkie myśli postronne, które działają w nas na podobieństwo nieszczelności w urządzeniu grzewczym, wytwarzającym wysoką temperaturę. Zanim ciepło dostanie się do ogrzewanych pomieszczeń, wychładza się ze względu na nieszczelności. Podobnie dzieje się podczas modlitwy, gdy umysł przyjmuje postronne myśli. Modlitwa jest przewodnikiem przekazującym ciepło, natomiast postronne myśli, stratami ciepła. Czym więcej strat, tym mniejsza wydajność modlitwy ${ }^{34}$.

Modlitwa jest wezwaniem Jezusa Chrystusa nieustannym, aby przyniosła rezultat. Co jednak czynimy? Mówimy modlitwę dziesięć minut, następnie męczymy się i potrzebujemy odpocząć. Jeśli przerwiemy modlitwę raz lub więcej, to w pewnym momencie ją porzucimy. Wręcz przeciwnie, gdy będziemy przyzywać nieustannie i niestrudzenie Chrystusa, wówczas On nie dopuści szatana aby nas nękał. Mianowicie, nie pozwoli aby rozwijał w nas niepożądane myśli, rysując $\mathrm{w}$ naszym umyśle obrazy grzechu. Kiedy, zatem zwodzi nas kusiciel? Gdy zapragniemy grzechu, ale wstydzimy się lub boimy się, dlatego szukamy odpowiedniej chwili do usprawiedliwienia naszego czynu. Wówczas szatan otrzymuje prawo, aby wejść do naszego serca i wyryć w nim obrazy grzechu. Jeśli jednak nasza modlitwa jest nieustanna, wówczas wiatry nieczystych duchów nie mogą skazić naszego wnętrza, a tam gdzie czyste serce, zawsze przebywa boskie światło Jezusa Chrystusa, tam zawsze przebywa pokój, rozkosz, radość i łaska ${ }^{35}$.

Lepszej pomocy od modlitwy jezusowej nie znajdziemy w całym naszym życiu, ponieważ modlitwa jest przyzywaniem i zastosowaniem imienia Jezusa, które nam daje Jego moc. Przyzywając imię Jezus, przyjmujemy Go za swego sprawcę. Gdziekolwiek byśmy się udali, nigdzie nie znajdziemy lepszej pomocy i sprawcy od Jezusa, al-

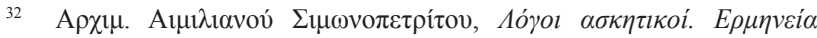

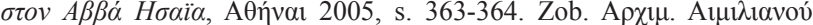
$\Sigma$ ¿

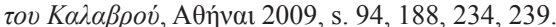

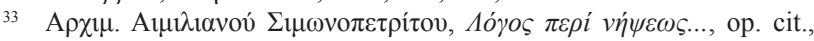
s. $106-107$

34 Tamże, s. 133-134

35 Tamże, s. 544-556.
}

bowiem tylko On zna najlepiej sztuczki szatańskie i jest w stanie z nimi poradzić. Częstokroć nie zdajemy sobie sprawy, że żyjemy beztrosko. W większości przypadków, gdy jesteśmy zajęci samym sobą, naszymi problemami, troskami, pragnieniami, jakimikolwiek innymi odczucia$\mathrm{mi}$, w tym czasie znajdujemy się pogrążenie w głębokim śnie, nie zdając sobie sprawy, że demony świętują, panosząc się w naszym sercu, a my zadajemy tym samym śmiertelny cios samym sobie. Dlatego tak ważnym jest abyśmy pozwolili Chrystusowi, aby zaistniał i zamieszkał na stałe w naszym życiu ${ }^{36}$. Jeśli szczerze pragniemy pozbyć się złych myśli, za którymi stoją nasze namiętności i demony, jeśli prawdziwie pragniemy uspokojenia i radości, aby serce nasze było trzeźwe, należy modlitwę jezusową połączyć z oddechem ${ }^{37}$.

Wiele razy deklarujemy swą miłość do Boga, wręcz ją wyśpiewujemy, ale nie jesteśmy w stanie trwać bez roztargnienia przy nieprzerwanej modlitwie. Kłamiemy, gdyż autentyczna miłość do Boga jest stwórczą przyczyną niezakłóconej modlitwy. Jeśli pragniemy sprawdzić czy miłujemy Boga, należy zwrócić uwagę czy modlitwy się bez roztargnienia, czy mianowicie nasz umysł nie rozprasza się, nie toczy walki z pożądaniami, myślami, namiętnościami, gdyż miłość Boża jest otaczającym murem który nie dopuszcza niczego do naszego rozumnego świata. Możemy zatem być pewni, że kochamy Boga gdy nie zakłócamy naszego umysłu przez jakiekolwiek myśli, fantazje, działania, namiętności i pragnienia. Niezakłócona modlitwa jest łatwym sposobem, aby sprawdzić naszą miłość do Boga $^{38}$. Kto osiagnie taki stan modlitwy, zawarł mistyczny związek małżeński z Bogiem, może zawołać alleluja Objawienia, hymn oblubieńczy do Boga. Modlitwa jest przezwyciężeniem czasowości i wejściem w ponadczasowość, nieskończoność, doskonałość oraz genialność Boga. Zatem jest swoistym złączeniem nas z Bogiem i perychorezą nas w Bogu, swoistym zniknięciem nas w Bogu, staniem się w Nim jednym. To wszystko dzieje się za przyczyną modlitwy i jest modlitwą. Dlatego miłość i modlitwa posiadają tak bliski związek z sobą, że jedno oznacza to drugie ${ }^{39}$.

W innym miejscu starzec Emilian ostrzega przed pochopnym osądzaniem modlitwy własnego autorstwa pod pretekstem, że jest pochodzenia protestanckiego. Modlitwa „Ojcze nasz” jest własną modlitwą Jezusa Chrystusa, wszystkie teksty cerkiewne są pełne od własnych modlitw, wszyscy Ojcowie posiadają w swej twórczości własne modlitwy, zatem własną modlitwę może czynić praktykować serce. Jako przykład podaje starca Efrema z Katunakion, który zapytany jak czynić modlitwę, odpowiadał, że po pierwsze należy zacząć swą modlitwę serdeczną, otworzyć swe serce, rozpocząć rozmowę z wielką słodyczą z Chrystusem, Bogarodzicą, naszą „matulą” i dopiero następnie przejść do modlitwy właściwej. Z chwilą gdy Cerkiew wprowadziła nas do prawidłowych teologicznie, pedago-

\footnotetext{
36 Tamże, s. 221-222.

37 Tamże, s. 347-348, 557-558.

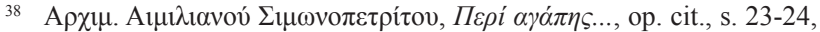
$55-56$

39 Tamże, s. 26-27.
} 
gicznie i duchowo środków wiodących nas ku niebu, mianowicie zatwierdzając przyjęte w Cerkwi modlitwy, należy się im pierwszeństwo, ponieważ wspólnota wiernych ma zawsze pierwsze słowo przed Bogiem. Modlitwa własna jest właściwa, gdy jest zgoda z zasadą posłuszeństwa Cer$\mathrm{kwi}^{40}$.

Istotne miejsce w twórczości ihumena Emiliana zajmuje modlitwa przed nabożeństwem lub inaczej reguła

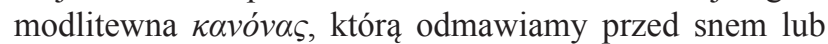
w nocy i przed porannym nabożeństwem. Spośród dwóch rodzajów reguł lepsza jest ta nocna ${ }^{41}$, ponieważ gdy po wstaniu z łóżka od razu udajemy się na nabożeństwo wówczas nie będziemy się w stanie właściwie skupić na modlitwie. Człowiek potrzebuje przynajmniej dwóch godzi do przebudzenia się, aby jego serce rozgrzało się, aby mogło wznieść się na niebo. Powinniśmy zatem wyrobić w sobie zwyczaj wstawania czym wcześniej możemy, wówczas nasza dusza będzie w stanie rozwinąć skrzydła modlitwy. Podczas reguły modlitewnej, jeśli nie możemy się modlić przez dłuższy czas, czytamy Stary i Nowy Testament, Ojców Cerkwi lub Psałterz ${ }^{42}$, aby wspomóc naszą ludzką niemoc. Czytania ${ }^{43}$ nie są przypadkową nauką ale tą która uprawia obszary naszego serca, umysłu, wnosi pokój, abyśmy mogli ożywić naszą modlitwę. Powinna stać się nośnikiem Bożym, donośnym krzykiem który dosięgnie niebios. Do modlitwy włączamy zatem czytania ponieważ są czynnikiem wprowadzającym do niej. Jednak czym bardziej nasza dusza wznosi się ku Bogu, tym bardziej ogranicza czytanie na rzecz zwiększenia modlitwy. Podobnie ma się rzecz z wieczernią. Tuż przed wyjściem do cerkwi dobrze jest pomodlić się trochę w swej celi ${ }^{44}$.

Doznaniem (odczuciem) modlitwy jest głębokie

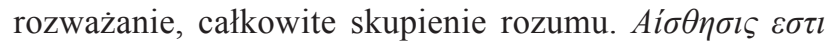
$\pi \rho o \sigma \varepsilon v \chi \eta ́ \eta, ~ \sigma o ́ v v o l \alpha \mu \varepsilon \tau^{\prime} \varepsilon \beta \lambda \alpha \beta \varepsilon i \alpha \varsigma$. Zatem modlitwa jest rozważaniem $\sigma o ́ v v o l \alpha$, ale również pozbyciem się wszelkiego rodzaju myśli i fantazji, ponieważ naszym celem jest aby nasz umysł wzniósł się ku Bogu. Rozważaniom towarzyszy pobożność, wynikająca z pewnej wewnętrznej bojaźni Bożej, gdyż poznaliśmy wielkość Boga, oraz co czynimy w danej chwili, że w pewien sposób wchodzimy w obszar boskości, wstępujemy na niebo, wchodzimy tam gdzie jedynie niematerialne umysły posiadają prawo wstępowania.

Pojęciu rozważania towarzyszy skupienie i wycisze-

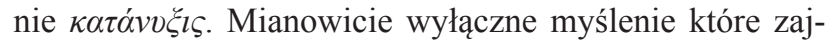
muje nasz umysł jest Bóg, powoduje pewne poruszenie, pewien ból duszy. Ponieważ nasze serce jest zwykle związane z ziemskimi sprawami i pozostaje w ścisłym związku

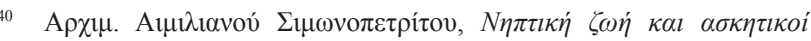

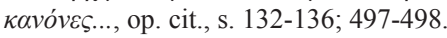

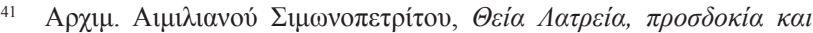

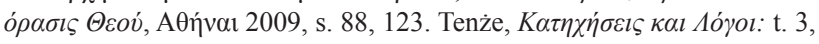

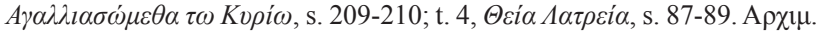

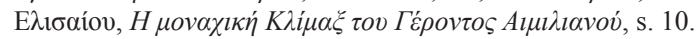

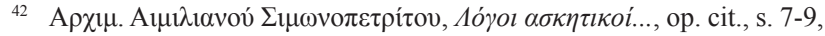
74-75, 187-188.

43 Tamże, s. 292.

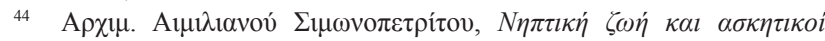

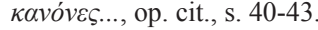

z naszą cielesnością, dlatego też potrzebujemy owego poruszenia serca i skupienia, dzięki którym jesteśmy w stanie wyrzec się wszelkiego wygodnictwa i zapragnąc wyższego życia, niezakłócanego przez ból, wyrzuty sumienia oraz okoliczności, które upokarzają umysł i ducha.

Rozpacz duszy jest czymś głębszym od rozważania, jest całkowitym zrozumieniem stanu upadłości, w którym żyje nasza dusza oraz świadomość swej marności. Zatem rozpacz duszy wynika pierwotnie z uczucia swej nicości, zaś poprzedza ją pobożność pochodząca $\mathrm{z}$ znajomości i uczucia świętości i potęgi Boga. W rezultacie widząc, że jesteśmy niczym w obliczu wspaniałości Boga, rozpaczam w swej duszy, gdyż widzę że cokolwiek najlepszego i najdoskonalszego miałbym przynieść Bogu nie jest niczym innym, niż zaprzeczeniem samego Boga ${ }^{45}$.

Ten kto pragnie modlić się nie pada w ciężkie grzechy, jedynie na skutek nieostrożności, niewiedzy lub pośpiechu odnośnie małych upadków. Człowiek pragnący komunikować się z Bogiem nie grzeszy, ponieważ już narodził się z Ojca i z Ducha Świętego ${ }^{46}$, zatem nie jest możliwym przyjmowanie działania w sobie grzechu.

Rozważaniom modlitewnym towarzyszą wzdychania i opłakiwania. Wzdycha nasze serce pod ciężarem ziemskości ciała. Przez ciało rozumiemy także duszę, która jest obarczona ciężarem jej upadku i oddaleniem od Boga. Czy znajdując się wśród ludzi, czy sami, staramy się aby nasz żal, wzdychania był wyrazem naszego wnętrza, a nie jawnym pokazem. Również, staramy się aby wzdychania nie stały się przyczyną stresu, ran psychicznych, czy depresji, ale aby wywołały tylko radość w Dychu Świętym ${ }^{47}$.

Gdy rozpoczynamy życie duchowe, postarajmy się mieć $\mathrm{w}$ pamięci Boga. Jest to wysiłek umysłowy, nie jest jeszcze porywem naszego umysłu, ale ukłonem naszej rozumnej części, naszej pamięci ku Bogu. Nie dążmy do przyjemności, wizji i przeżyć. My mamy pamięć Bożą i oddajemy się Jemu, naszemu jedynemu dobru, bez zajmowania się dążeniami: radością, niebiańskimi objawieniami, nic absolutnie. W przypadku początkujących, naszym wyłącznym dobrem jest pamięć Boża, w innym razie poddamy się pokusom i oddalimy się od Boga. Pozostając przy pamięci Bożej, otrzymamy od samego Boga charyzmaty. Należy dążyć do zachowania pamięci Bożej również w czasie pracy, ponieważ szkoda, aby te godziny zostały zaprzepaszczone i w ogóle w życiu powszednim, gdziekolwiek jesteśmy w szczególności gdy znajdujemy się na modlitwie. Mianowicie cały dzień niech zajmuje nas modlitwa, a w szczególności szczególne godziny kiedy poświęcamy jej swój czas ${ }^{48}$.

Podczas naszej indywidualnej modlitwy i podczas pracy postarajmy się myśleć wyłącznie o Bogu. Gdy znajdujemy się w świątyni, należy dążyć do zrozumienia słyszanego nabożeństwa, bez usiłowania uczynienia egzegezy,

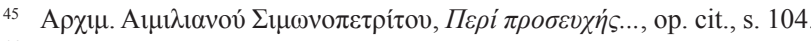
46 I J. 3,9.

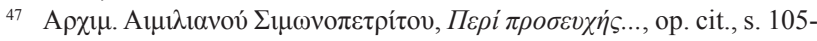
-106 .

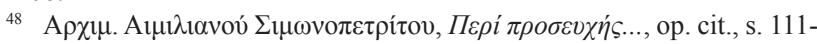

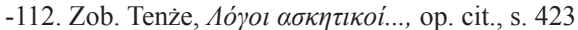


ale z otwartym sercem, aby wchodziły do środka pojęcia, wówczas Bóg dokona niezbędnej egzegezy i objawienia w naszych duszach. Należy to czynić bez przeżywania i na siłę, bez wymuszania na naszej woli. Jeśli modlitwa nas męczy, tzn. jeśli wywiera przeciwny skutek w naszej duszy, wówczas należy natychmiast zatrzymać się. Nie należy wymuszać modlitwy, stresować się. W takich chwilach należy przespacerować się, wyjść na zewnątrz na podwórze, cokolwiek uczyńmy, pozwólmy naszemu umysłowi aby powrócił z radością do Boga ${ }^{49}$. Człowiek jest zmienny, jest pod wpływem stanu swego zdrowia, klimatu, ludzi, swego stanu psychicznego, nie jest zawsze taki sam. Nie należy, zatem nas interesować, czy za każdym razem nasza modlitwa będzie płodną. Powinniśmy wypełniać swą regułę modlitewną w określonym czasie. To, w jakim stanie będziemy jest sprawa Bożą. Bóg oczekuję abyśmy ucztowali się modlitwą. Plon modlitwy jest wiadomy wyłącznie Bogu, przy czym nie odpowiemy za dzieło Boże, ale za własne czyny ${ }^{50}$.

Należy uważać aby nasza modlitwa nie stała się powodem odizolowania się od innych, ponieważ wówczas będzie kłamliwą i nieszczerą, całkowicie przyziemną, cielesną i egoistyczną. Powinna być czyniona w absolutnej harmonii i zgodzie z bliźnimi, z całkowicie pokornym usposobieniem, ustępliwością w myślach, wobec woli i pragnienia drugiego człowieka. Należy być gotowym poświęcić nawet naszą modlitwę ze względu na bliźniego, jeśli zaistnieje taka potrzeba. Jeśli nawet doświadczą nas trudności, nasz umysł powinien być całkowicie wolnym-pustym od wszelkich postronnych myśli, nawet tych dobrych, które postaramy się oddalić od siebie bez zamartwiania się i spinania. Wyrzekamy się wszystkiego. I jeśli nie rozumiemy co oznacza stanie przed Bogiem, rozumiemy słowa „Panie Jezu Chryste, zmiłuj się nade mną grzesznym", wówczas nasza pamięć będzie w Bogu, zgodnie ze powyższymi słowami ${ }^{51}$.

Czym wolniej wymawiamy modlitwę tym lepiej. Jeśli ktoś podczas modlitwy odczuwa ból głowy, powodem jest spinanie się. Modlitwa ta nie jest praca umysłową, która męczy, gdyż kieruje się ku rzeczom ludzkim, skoro umysł jest stworzony do wchodzenia ku Bogu. Gdy umysł jest skierowany na Boga i ku Niemu podąża, to tak jakby człowiek wszedł do jego ogrodu i rozkoszuje się zapachem wonnych kwiatów. Dlatego nie męczy się ale odpoczywa. Co innego oznacza tzw. duchowa czy umysłowa praca, która jest sztucznym tworem i prowadzi do przemęczenia się, a co innego modlitwa. Modlitwa może wywołać ból głowy, jedynie wówczas gdy jest źle odmawiana, lub u początkujących. Modlitwa z doznaniem serca przynosi odpoczynek, gdyż jest twoją, zrozumiałą przez ciebie, masz z nią związek i radujesz się. $\mathrm{W}$ in-

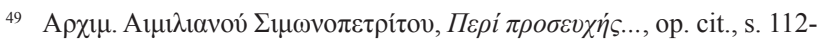
$-113$

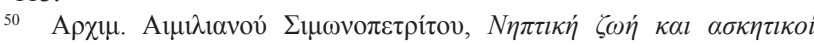

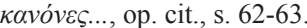

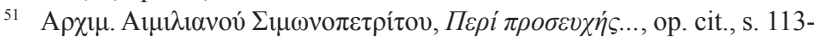
$-114$
}

nym razie wydaje się tobie, że jest czymś rozłącznym, obcym $^{52}$.

Pamięć o Bogu nie jest praca umysłową, zatem nie męczy. Wspominając tego kogo kochamy nie męczymy się ale radujemy się. Jeśli jednak dana osoba zaczyna oddalać się, stronić od nas, czynić problemy, wówczas sama myśl o nim przysparza nas o ból głowy. Podobnie gdy nie przeciwstawiamy naszej woli Bogu, nasz umysł jest całkowicie swobodny, wypoczęty. Jednak gdy sprzeciwiamy się, wówczas odczuwamy zmęczenie. Ponieważ wówczas nie męczymy umysłu, ale duszę $e^{53}$.

O modlitwie wewnętrznej mówimy, gdy duch ludzki, uwolniony od poruszeń duszy kontaktuje się i łączy z Bogiem. Wówczas nawet podczas snu lub pracy modli się. Należy zatem dokładać starań aby modlić się podczas pracy.

Modlitwa nie jest celem, ale środkiem w dążeniu do uzyskaniu rezultatu. Oczekiwanym efektem jest natomiast pokój i zjednoczenie z Bogiem, łączność z Bogiem. Jednak kiedy nie czynimy modlitwy, żyjemy życiem przeciętnym, dlatego nie dostrzegamy istotnych problemów. Przeciwnie, gdy modlimy się, wówczas ukazują się myśli które wcześniej nie przeszły by przez głowę, głównie te przeciwstawne myśli, wprowadzające nas w zakłopotanie z powodu pojawiających się myśli lub pokus, o których nawet byśmy nie przypuszczali. Przykładowo możemy stanąc przed problemem wiary w Boga, wiary w królestwo niebios itp. Od razu ciśnie się pytanie. Dlaczego akurat teraz przytrafia się nam to wszystko? Ponieważ teraz zaczynamy modlitwę, teraz modlitwa zaczyna dawać plon. Teraz także zauważają nas nasi przeciwnicy, którzy rozpoczynają nas dręczyć. Należy zachować męstwo, ponieważ te problemy wymagają cierpliwości w strzeżeniu umysłu i wywołują pewien ból w duszy. Do momentu gdy nie modliliśmy się, nie odczuwaliśmy szczególnie istotnych problemów. Teraz jednak gdy weszliśmy w dzieło modlitwy, należy się przygotować na trudności polegające na szykanach i udrękach, pomijaniu ze strony innych i unikaniu, co w konsekwencji może wywołać poważne problemy w naszej duszy. Dlatego należy uzbroić się w męstwo, aby nasz umysł nie poddał się tym problemom i nie popadł w smutek, ale pozostał skupiony wyłącznie na Bogu. Wówczas nie stracimy Chrystusa, który zechciał narodzić się w naszej duszy oraz pozostałego plonu otrzymanego za pośrednictwem modlitwy ${ }^{54}$.

Chrystus objawia się w czasie modlitwy. Mamy zatem do czynienia nie z pośrednim objawieniem, ale bezpośrednim. Jeśli chcemy zrozumieć Boga powinniśmy się modlić do Niego bezpośrednio, a On wówczas do nas przemówi. Naturalny stan modlitwy jest tworzony za sprawą laski Bożej oraz jej pozyskania, uzależnionej jednak od naszego własnego usposobienia i myśli, czego rezultatem jest pochwycenie naszego umysłu. Stanem modlitwy jest $\varepsilon^{\prime} \xi \xi \iota \varsigma \alpha \pi \alpha \theta \dot{\eta} \varsigma$. Jest stanem, przyzwyczajeniem, zwyczajem

\footnotetext{
52 Tamże, s. 114-115.

53 Tamże, s. 115-116.

54 Tamże, s. 124-126.
} 
umysłu i ducha w beznamiętności, niezmienności, z wewnętrzną ciszą i spokojem. Każde przyzwyczajenie és̆lৎ, tworzy pewną skłonność, pragnienie lub zainteresowanie.

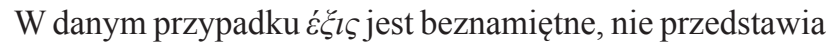
żadnego zainteresowania, z tym wyjątkiem, iż znajduje się w głębi naszej duszy. W celu uwieńczenia każdej cnoty niezbędną jest modlitwa, która jest stanem beznamiętności

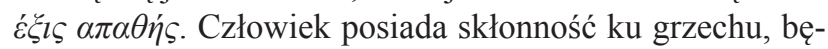
dącą przyczyną jego męczarni oraz podstępnym wrogiem, który w każdej chwili może go zwieść. Aby przezwyciężyć skłonność do grzechu niezbędne jest przeciwstawne przyzwyczajenie, ale już beznamiętne éšlৎ $\alpha \pi \alpha \theta \dot{\eta} \varsigma$. Pociąg do grzechu jest namiętnością rozkoszującą się przyjemnością i zwodzi człowieka ku zatraceniu. Natomiast przyzwyczajenie do beznamiętności nie jest stanem, który zwodzi. Skoro jest beznamiętne nie wzbudza w nas niepokoju, nie uprowadza, nie ciągnie, nie wstrząsa, ale my go pragniemy, kierowani własną nieprzymuszoną wolą $a^{55}$.

Stan modlitwy nie jest po prostu przychodzącą od Boga łaską, ale posiada rezultat, beznamiętną miłosną skłonność, pragnienie i przyciąganie do Boga. Chrześcijanin nie jest martwy nie pozostaje w bezruchu, bez działania. Oczywiście jest martwy dla grzechu, ale jego droga ku Bogu jest bardzo intensywna. Stan modlitwy jest mocą, dynamiczną formą, energią całego człowieka, który nie może nigdzie siebie odnaleźć, czy realizować, niż poruszając się mądrze ku poszukiwanemu i upragnionemu Bogu. Stan modlitwy to pełnia dynamizmu, nakierowana na Boga. Każdy inny dynamizm nie ma racji bytu. Zatem, gdy ktoś posiada zewnętrzny dynamizm, nie jest możliwym, aby posiadał także wewnętrzny. Ponadto, człowiek który w relacjach $\mathrm{z}$ innymi ludźmi jest porywczy i gwałtowny oraz roszczeniowy, to należy postawić wielki znak zapytania, czy może być także dynamiczny w Bogu. Dynamiczny w Bogu jest zatem martwy wobec wszystkiego co jest Jemu obce. Nie chodzi wyłącznie o pojęcie obojętności, ale także znaczenie niezdolności czynienia czegokolwiek, co jest obce i odsuwa nas od Boga ${ }^{56}$.

Kiedy zrozumiemy, że zaczęliśmy się modlić zgodnie z założeniami i zasadami modlitwy, że nasz umysł zaczął wznosić modlitwę do Boga? Po pierwsze, gdy nasz umysł jest przepełniony miłością i pragnieniem Boga. Po drugie, gdy pomału oddala się od całego naszego życia, mianowicie, wówczas, gdy nasz umysł zaprzestaje przyjmowania bodźców z otaczającego świata, skupiających wokół cielesności, tak bardzo, jakby miał opuścić swoje ciało, wyjść z siebie, jakby miał wznieść się na niebo i pozostawać tam

Tamże, s. 128-129

56 Tamże, s. 130. zawieszonym jak meteor razem z Bogiem. Po trzecie, gdy osiąga stan umysłu i duchową sprawność natychmiastowego oddalania od siebie każdego zamysłu przychodzącego z zewnątrz. Oczywiście dana myśl może wychodzić ze środka nas samych, może mieć związek z naszymi namiętnościami, pragnieniami, ale i to pozostaje poza życiem umysłu, który odłączył się już od naszego ciała, od naszego całego życia, i czuje się jakby obcy z czymkolwiek co ma związek z życiem codziennym. Po czwarte, gdy nasz umysł jest pełny od radości i pobożności ku Bogu, mianowicie pełny od uczucia majestatu Bożego i własnej małości, która rzuca na kolana w obliczu Boga. Gdy posiądziemy to wszystko, znaczy że rozpoczęliśmy modlitwę do Boga. Inaczej, możemy błagać Boga, możemy wyznawać swe troski, pragnienia, jednak nie to łączy nas z Nim, jedynie czynią z nas klęczącymi błagalnikami Jego miłości ${ }^{57}$.

Starzec Emilian określa modlitwę charyzmą, niebiańskim radosnym spotkaniem i komunią Boga z człowiekiem. Sztuka modlitwy w doświadczeniu filokalistycznym starca jest uzależniona od stanu naszego umysłu, który powinien być czysty, pozbawiony wszelkiej obcej treści w oczekiwaniu przyjścia Boga. Prawdziwa modlitwa odrzuca wszelki smutek i małoduszność, zaś ramki prawa w których może zaistnieć są określane przez pokój, ciszę, spokój ducha, absolutne wyciszenie i milczenie. W rzeczywistości modlitwa nie jest czymś, co czyni sam człowiek, jedynie to rozpoczyna, tego pragnie, ale wypełnia ją Duch Święty. Modlitwa jest naszą powszednią powinnością życiową. O sukcesie podczas modlitwy możemy mówić wówczas, gdy stanie się naszym miejscem schronienia. W swym nauczaniu starzec rozróżnia czynniki wewnętrzne i zewnętrzne, które mają wpływ na modlitwę. Do pierwszych zalicza stan naszego ducha i jego związek z Bogiem, zaś modlitwę określa mianem homilii umysłu, oddechem ducha, pokłonem oddawanym Bogu. Do drugich zalicza wiedzę o różnych sposobach modlitwy, niezbędną do mistycznego natchnienia przez Ducha Świętego. Takimi są uczestnictwo w liturgii Bożej, modlitwa nieustanna, jezusowa i własna, reguła modlitewna, rozważania w skupieniu i wyciszeniu. Modlitwa nie izoluje się sama w sobie, ale pozostaje w ścisłym związku z uczestnictwem w nabożeństwach, dziękczynieniem, czuwaniem, w celu pokonania cielesnych namiętności. Starzec przestrzega przy tym, aby modlitwa nie stała się powodem odizolowania, ponieważ wówczas stanie się kłamliwą i nieszczerą. Modlitwa nie jest pracą umysłową która męczy, ale jest pełnią dynamizmu nakierowanego na Boga.

\footnotetext{
57 Tamże, s. 137-138.
} 


\section{Bibliografia}

\section{Materialy źródlowe}

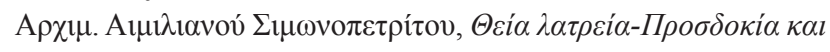
ó $\rho \alpha \sigma l \varsigma \Theta \varepsilon o v ́$, A $\theta \dot{v} v \alpha r 2009$.

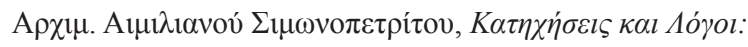

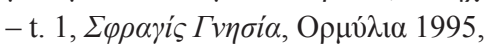

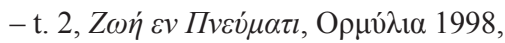

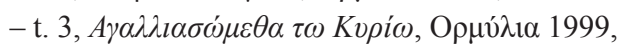

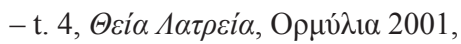

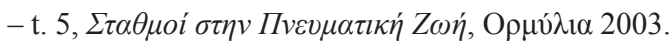

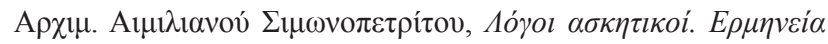

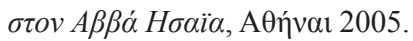

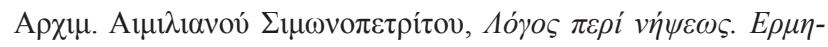

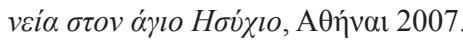

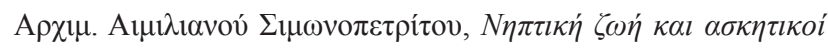

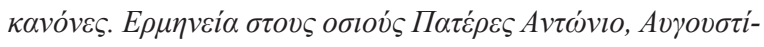

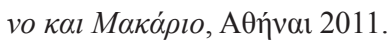

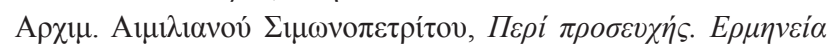

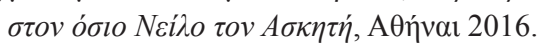

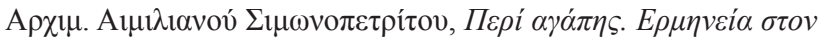

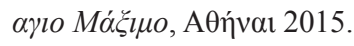

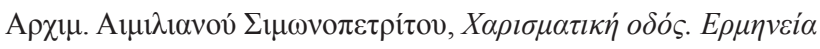

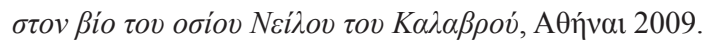

\section{Opracowania}

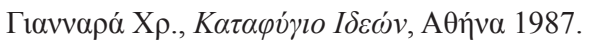

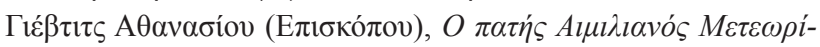

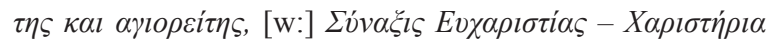

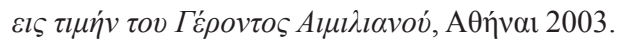

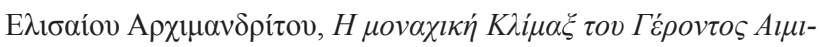

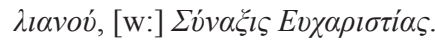

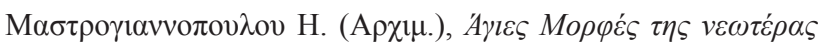

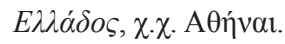

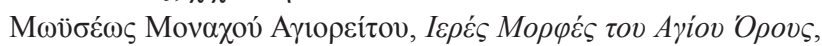

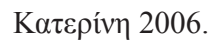

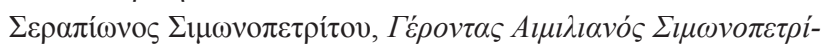

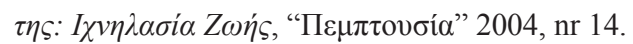

Rozmiar artykułu: 1,4 arkusza wydawniczego 
ISSN 1508-7719

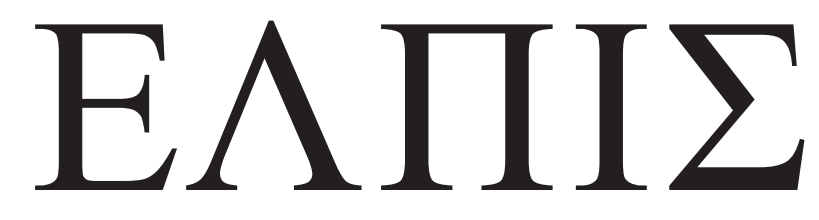

CZASOPISMO TEOLOGICZNE KATEDRY TEOLOGII PRAWOSŁAWNEJ UNIWERSYTETU W BIAŁYMSTOKU

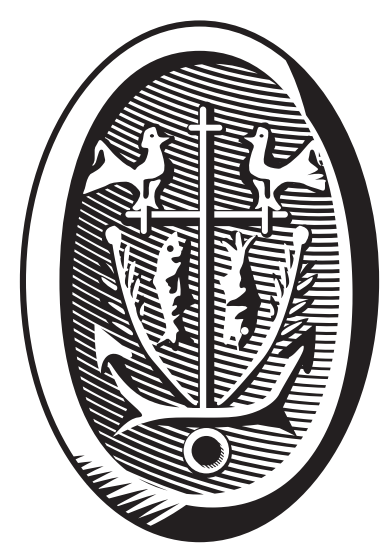

ADRES REDAKCJI

15-097 Białystok, ul. M. Skłodowskiej-Curie 14 tel. 85 745-77-80, e-mail: redakcja@elpis.edu.pl www.elpis.uwb.edu.pl 